\section{Specificity of the Local Government Elections in the Opolskie Province in 2018}

\author{
Marcin Ociepa
University of Opole, Poland
(D) https://orcid.org/0000-0002-9748-160X \\ Marcin Ociepa
University of Opole, Poland
(D) https://orcid.org/0000-0002-9748-160X \\ Marcin Ociepa
University of Opole, Poland
(iD) https://orcid.org/0000-0002-9748-160X
}

Political Preferences

2020, vol. 26: 5-26

journals.us.edu.pl/index.php/PP

Submitted: $25 / 03 / 2020$

Accepted: 08/06/2020

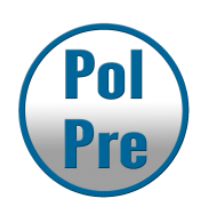

\begin{abstract}
:
The objective of this paper is to analyse the political activity of the local community of the Opolskie Province in the local government elections in 2018 and to identify the characteristic features determining its specificity. The attempt to identify the electoral specificity of the region will consist in presenting a characterization of the region in terms of its size and population as well as its administrative and social aspects. An analysis of the elements inseparably connected with the election process, such as geography, voting turnout, the number of electoral registers and candidates, the types of electoral committees, is equally important. And finally, comments on the election results are significant as well. The local government elections of 2018 were held in a specific atmosphere, largely related to the amendment of the election law. Undoubtedly, the most characteristic aspect for the Opolskie Region is its last position among other provinces with regard to size and population, but it should not be forgotten that it is a borderland region inhabited by a high percentage of the German national minority, which actively shapes the image of not only the local communities at every level, but also the entire Opolskie Region as such.
\end{abstract}

Keywords: local government elections, local elections, elections in Opolskie Province, 2018 local government elections in Opolskie Province

\title{
Introduction
}

A modern democracy cannot exist without elections; it is citizens' participation in the election of their representatives in governing bodies that legitimizes their authority (Wojtasik 2011). This is particularly important at the local government level, where voters feel that they are able to influence directly local politics, that they are participants in and beneficiaries of government, and they share responsibility for the local community (Tybuchowska-Hartlińska 2012). Local government elections are an excellent opportunity to articulate voters' specific needs and interests (Oliver et al. 2012; Stoker 1991), and subsequently, by winning elections or introducing their representatives to local governing bodies, to pursue them. 


\section{Marcin Ociepa}

The objective of this paper is to analyse the political activity of the local community in the local government elections in 2018 in the Opolskie Province and to identify the characteristics determining its specificity.

The local government elections of 2018 were exceptional, as they were held in a special atmosphere, largely related to the change in the electoral law, which comprised the Electoral Code and the following parliamentary acts: on communal, district, and provincial government, as well as the government system of the capital city of Warsaw, introduced by the act of 11 January 2018 amending certain laws aimed at increasing citizens' participation in the process of election, the functioning and supervision of certain public bodies, which entered into force on 31 January 2018 (Journal of Laws 2018). This act introduced a number of very important changes to the electoral system at the local government level, including for instance a system in which commune leaders, town mayors and city presidents can hold office for two terms only; an extension of the term of office of commune councils, district councils and provincial assemblies from four to five years; a limitation of single-seat constituencies to communes with a population of up to 20,000 persons; an establishment of two types of precinct election commissions (for conducting the voting process and for establishing voting results); granting the right to appoint one social observer in the precinct, regional, district and territorial election commissions to associations and foundations whose statutory objectives comprise concern for democracy, civil rights and the development of the civil society (PAP 2018).

Under these new conditions, the Opolskie province and 15 other provinces had to face the election of new local governing bodies. The attempt to identify the electoral specificity of the region will consist in presenting a description of the region in terms of its size and population, as well as its administrative and social aspects. An analysis of the elements inseparably connected with the election process, such as geography, voting turnout, the number of electoral registers and candidates, the types of electoral committees, is equally important. And finally, comments on the election results are significant as well.

Undoubtedly, the most characteristic aspect of the Opole Region is its last position among other provinces with regard to size and population, but it should not be forgotten that it is a borderland region (Ganowicz 2014), inhabited by a high percentage of the German national minority, which actively shapes the image of not only the local communities at every level, but also the entire Opole Region as such. 


\section{Description of the Opolskie province}

The Opolskie province is situated in the south of Poland, between the Dolnośląskie and Śląskie provinces. It neighbours the Czech Republic as well as the Łódzkie and Wielkopolskie provinces. Its surface area is $9411.87 \mathrm{~km}^{2}$, which makes it the smallest of all provinces in Poland. Similarly, it has the smallest population: 950,464 inhabitants in 2018, which places the province at the very end of the list (Table 1). The province is also among those with a negative rate of natural growth and a progressing outflow of population (GUS 2019).

Table 1. The Opolskie province among the other provinces in Poland

\begin{tabular}{lrrrc}
\hline Province & Inhabitants & \multicolumn{1}{c}{ Voters } & $\begin{array}{c}\text { Election } \\
\text { precincts }\end{array}$ & $\begin{array}{c}\text { Provincial assembly } \\
\text { constituencies }\end{array}$ \\
\hline Dolnośląskie & $2,755,957$ & $2,273,653$ & 1,940 & 5 \\
Kujawsko-pomorskie & $1,978,984$ & $1,610,340$ & 1,651 & 6 \\
Lubelskie & $2,099,846$ & $1,717,638$ & 1,892 & 5 \\
Lubuskie & 974,567 & 791,991 & 719 & 5 \\
Łódzkie & $2,390,845$ & $1,976,999$ & 1,732 & 5 \\
Małopolskie & $3,305,730$ & $2,656,449$ & 2,408 & 6 \\
Mazowieckie & $5,199,604$ & $4,186,479$ & 3,468 & 7 \\
Opolskie & $\mathbf{9 5 0 , 4 6 3}$ & $\mathbf{7 9 2 , 4 5 6}$ & $\mathbf{8 8 0}$ & $\mathbf{5}$ \\
Podkarpackie & $2,116,059$ & $1,714,950$ & 1,805 & 5 \\
Podlaskie & $1,153,371$ & 941,772 & 959 & 4 \\
Pomorskie & $2,208,934$ & $1,759,938$ & 1,392 & 5 \\
Śląskie & $4,310,345$ & $3,548,892$ & 2,745 & 7 \\
Świętokrzyskie & 1,2329263 & $1,020,502$ & 982 & 4 \\
Warmińsko-mazurskie & $1,387,270$ & $1,126,306$ & 1,111 & 5 \\
Wielkopolskie & $3,369,873$ & $2,710,628$ & 2,179 & 6 \\
Zachodniopomorskie & $1,604,980$ & $1,316,823$ & 1120 & 5 \\
Summary & $\mathbf{3 7 , 0 3 9 , 7 5 4}$ & $\mathbf{3 0 , 1 4 5 , 8 1 6}$ & $\mathbf{2 6 , 9 8 3}$ & $\mathbf{8 5}$ \\
\hline Sourc: PKW (2018) & & & & \\
\hline
\end{tabular}

Source: PKW (2018).

The fact of being the smallest of the provinces with the lowest number of inhabitants certainly determines also the electoral geography of the region. The numbers of voters, election precincts, and constituencies are the lowest here. As the table below shows, with its 792,456 voters, the Opolskie province was in the 15th place, only slightly ahead of the Lubuskie province (which is slightly larger in terms of surface area) with its 791,991 voters; similarly with respect to the number of precincts (880 in the Opolskie province, 719 in the Lubuskie province). 


\section{Marcin Ociepa}

Its 5 provincial assembly constituencies put the province at the same place as 8 others with the same number. Only the Świętokrzyskie and Podlaskie provinces have fewer constituencies.

Table 2. The Opolskie Province among other provinces with respect to the number of administrative units and the number of elected legislative and executive bodies

\begin{tabular}{|c|c|c|c|c|c|c|c|c|}
\hline \multirow{3}{*}{ Province } & \multirow{3}{*}{ Districts } & \multicolumn{4}{|c|}{$\begin{array}{l}\text { Number of } \\
\text { Communes }\end{array}$} & \multicolumn{3}{|c|}{ Number of elected } \\
\hline & & Total & & ncluding & & Commune & & \\
\hline & & & $\begin{array}{c}\text { district } \\
\text {-based } \\
\text { city }\end{array}$ & $\begin{array}{l}\text { above } \\
20,000\end{array}$ & $\begin{array}{l}\text { below } \\
20,000\end{array}$ & Leaders & Mrayors & presidents \\
\hline Dolnośląskie & 26 & 169 & 4 & 26 & 139 & 78 & 83 & 8 \\
\hline $\begin{array}{l}\text { Kujawsko- } \\
\text { Pomorskie }\end{array}$ & 19 & 144 & 4 & 9 & 131 & 92 & 47 & 5 \\
\hline Lubelskie & 20 & 213 & 4 & 9 & 200 & 165 & 43 & 5 \\
\hline Lubuskie & 12 & 82 & 2 & 8 & 72 & 39 & 40 & 3 \\
\hline Łódzkie & 21 & 177 & 3 & 14 & 160 & 133 & 33 & 11 \\
\hline Małopolskie & 19 & 182 & 3 & 30 & 149 & 120 & 58 & 4 \\
\hline Mazowieckie & 37 & 314 & 5 & 13 & 278 & 227 & 77 & 10 \\
\hline Opolskie & 11 & 71 & 1 & 10 & 60 & 35 & 34 & 2 \\
\hline Podkarpackie & 21 & 160 & 4 & 18 & 138 & 109 & 45 & 6 \\
\hline Podlaskie & 14 & 118 & 3 & 7 & 108 & 78 & 37 & 3 \\
\hline Pomorskie & 16 & 123 & 4 & 18 & 101 & 81 & 35 & 7 \\
\hline Śląskie & 17 & 167 & 19 & 22 & 126 & 96 & 47 & 24 \\
\hline Świętokrzyskie & 13 & 102 & 1 & 9 & 92 & 65 & 33 & 4 \\
\hline $\begin{array}{l}\text { Warmińsko- } \\
\text { Mazurskie }\end{array}$ & 19 & 116 & 2 & 13 & 101 & 66 & 47 & 3 \\
\hline Wielkopolskie & 31 & 226 & 4 & 30 & 192 & 113 & 106 & 7 \\
\hline $\begin{array}{l}\text { Zachodniopomor- } \\
\text { skie }\end{array}$ & 18 & 113 & 3 & 12 & 98 & 67 & 61 & 5 \\
\hline Summary & 314 & 2,477 & 66 & 248 & 2,145 & 1,544 & 826 & 107 \\
\hline
\end{tabular}

Being the smallest, the Opolskie province has the lowest number of administrative units. There are only 11 districts and one district-based city (Opole as the capital of the province) (The Opolskie Province in Numbers), 71 communes, most of which with a population of up to 20,000 persons (60), communes with a population of above 20,000 persons (10). The Opolskie province is characterized by the lowest number of commune leaders in the whole country (35). As far as mayors are concerned (34), the region was ahead of the Łódzkie and Świętokrzyskie provinces, 
where 33 mayors were elected respectively. The election of only two city presidents (Opole and Kędzierzyn-Koźle) gives Opole the last place in the ranking (Table 2).

The specificity of the image of Opolskie province is complemented by the fact that it is, to a significantly higher degree than other provinces, a multicultural borderland region (Mazurkiewicz 2015; Ganowicz \& Opioła 2017), which should be associated mainly with the existence of a group of the German minority (GM) representatives in Poland, inhabiting, according to the most recent reports (from a decade ago), the most numerously the central and eastern districts of the province: the Strzelecki district (20.62\% of residents of the province), the Opolski district (19.82\%), the Krapkowicki district (18.38\%), the Oleski district (16.82\%), the Prudnicki district (14.93\%), the Kędzierzynsko-Kozielski district (13.15\%), the Kluczborski district (9.75\%) and the Opolski city district (2.46\%)" (MSWiA 2020). According to the results of the 2002 National Census of Population and Housing, the German minority constitutes 10\% of the population (GUS 2002). Since the first local government elections in Poland, the presence of the German minority has been clearly visible, as has been the participation of the group in decision-making processes and in the exercise of power in the authorities of all three levels of the local government system. This political activity of the GM will certainly determine the most strongly the specificity of the elections in the region at each level (in different ways) and at all times, and the local government elections in 2018 were no exception in this respect.

\section{Voter turnout in the Opolskie Province}

The aforementioned elections, analysed from a general perspective, compared to the previous ones, in terms of one of the most important factors legitimizing each elected body, i.e. voter turnout, were characterized by a high level of citizens' activity. According to the National Electoral Commissionit was 48.83\% (PKW 2018), which was the highest voter turnout (in local government elections) after 1990. In every previous local government elections, the Opolskie province had been among the regions with the lowest voter turnout. As can be seen in the table below, in 2018, with the result slightly above $45 \%$ (45.36\%), the Opolskie province was ranked third from the bottom behind the Zachodniopomorskie province (45.14\%) and Śląskie province $(44.47 \%)$. 


\section{Marcin Ociepa}

Table 3. Voter turnout in particular provinces in the local government elections in 2018

\begin{tabular}{lrc}
\hline Province & Number of voters & Voter turnout \\
\hline Pomorskie & 581,223 & $52.75 \%$ \\
Małopolskie & $1,261,294$ & $52.20 \%$ \\
Mazowieckie & $1,132,170$ & $51.62 \%$ \\
Lubelskie & 633,171 & $51.62 \%$ \\
Świętokrzyskie & 445,092 & $51.57 \%$ \\
Podkarpackie & 441,077 & $49.56 \%$ \\
Łódzkie & 551,242 & $49.31 \%$ \\
Wielkopolskie & 574,921 & $47.67 \%$ \\
Podlaskie & 242,568 & $47.23 \%$ \\
Dolnośląskie & 572,893 & $46.50 \%$ \\
Warmińsko-mazurskie & 513,284 & $46.40 \%$ \\
Kujawsko-pomorskie & 424,907 & $46.25 \%$ \\
Lubuskie & 163,791 & $45.54 \%$ \\
Opolskie & $\mathbf{1 8 3 , 7 3 3}$ & $\mathbf{4 5 . 3 6 \%}$ \\
Zachodniopomorskie & 728,252 & $45.14 \%$ \\
Śląskie & $1,073,783$ & $44.47 \%$ \\
\hline Source: PKW (2018).
\end{tabular}

Source: PKW (2018).

In the Opolskie province, the highest voter turnout among the 11 districts was in two districts: Namysłowski (53.49\%) and Strzelecki (52.09\%). The lowest voter turnout was in the Opolski city district (41.93\%) and Nyski district (37.77\%). These data are illustrated in Table 4.

Table 4. Voter turnout in particular districts in the Opolskie Province in the local government elections in 2018

\begin{tabular}{lc}
\hline Districts & Voter turnout \\
\hline Brzeski & $45.18 \%$ \\
Głubczycki & $46.62 \%$ \\
Kędzierzyńsko-Kozielski & $45.69 \%$ \\
Kluczborski & $42.71 \%$ \\
Krapkowicki & $45.91 \%$ \\
Namysłowski & $52.49 \%$ \\
Nyski & $37.77 \%$ \\
Oleski & $44.81 \%$ \\
Opolski & $41.93 \%$ \\
Prudnicki & $46.58 \%$ \\
Strzelecki & $52.09 \%$ \\
\hline Source: PKW (2018). & \\
\hline
\end{tabular}


This voter turnout specificity of the Opole Region, perceived either externally or internally, turns out not to be so exceptional. The overall result, perhaps in the final registers, is not so much different from that in the Lubuskie province or a few provinces with higher places in the ranking. The situation is similar with respect to districts. Only the Nyski district clearly stands out, with the voter turnout below $40 \%$. One of the districts with a voter turnout higher than $50 \%$ (the Strzelecki district) is inhabited by a fairly large GM group, but this is also a characteristic of one of the districts with the lowest turnout, i.e. the Opolski city district. It is therefore difficult to see any clear characteristics here.

\section{Candidates and candidate lists}

An analysis of the elections cannot overlook the aspect of exercising the passive voting right. Table 5 shows that 186 commune council candidate lists in communes with a population of more than 20,000 persons, 32 district-based city council candidate lists, 225 district council candidate lists, and 56 provincial assembly candidate lists were registered in the Opolskie province. This is, respectively, $4.24 \%, 1.61 \%, 3.5 \%$, and $5.97 \%$ of all candidate lists registered in Poland. In total, the rolls in the Opolskie province represent only $3.64 \%$ of all rolls registered in Poland.

Table 5. Registered candidate lists in the 2018 local government elections in the Opole Province

\begin{tabular}{lccc}
\hline & Poland & Opolskie province & \% \\
\hline $\begin{array}{l}\text { commune councils in communes with more } \\
\text { than 20,000 inhabitants }\end{array}$ & 4386 & 186 & 4.24 \\
city councils in district-based cities & 1984 & 32 & 1.61 \\
district councils & 6413 & 225 & 3.50 \\
provincial assemblies & 937 & 56 & 5.97 \\
Total & $\mathbf{1 3 7 2 0}$ & $\mathbf{4 9 9}$ & $\mathbf{3 . 6 4}$ \\
\hline
\end{tabular}

Source: own work based on PKW (2018).

In the local government elections, 5690 candidates were registered, which constitutes $3.08 \%$ of all candidates registered in the country (184,745). 178 candidates were registered for the offices of commune leader, mayor, and city president - 75 for the office of commune leader, 93 for the office of mayor and 10 for the position of city president. This is $2.55 \%$ of all candidates for one of these offices in the province (6958). 
Table 6. The numbers of registered candidates in the 2018 local government elections in the Opolskie Province

Number of candidates

Number of registered candidates for seats on commune councils

in communes with a population of up to 20,000 inhabitants

Number of registered candidates for seats on commune councils

in communes with a population of more than 20,000 inhabitants

Number of registered candidates for seats on district-based city councils

Number of registered candidates for seats on district councils

Number of registered candidates for seats on the provincial assembly

Number of registered candidates for the office of mayor

Number of registered candidates for the office of city president

Number of registered candidates for the office of commune leader

Total

Source: own work based on PKW (2018).

The average age of candidates in the Opolskie province in general was 47 years; 45 years for women and 48 years for men (Table 7).

Table 7. The average age of candidates in the 2018 local elections in the Opolskie Province

Average age

Number of registered candidates for seats on commune councils in communes

with a population of up to 20,000 inhabitants

Number of registered candidates for seats on commune councils in communes

with a population of more than 20,000 inhabitants

Number of registered candidates for seats on district-based city councils

Number of registered candidates for seats on district councils

Number of registered candidates for seats on the provincial assembly

Number of registered candidates for the office of mayor

Number of registered candidates for the office of city president

Number of registered candidates for the office of commune leader

Source: own work based on PKW (2018). 
Among candidates for seats on councils, the highest number of candidates was recorded in the age range of 40-59 (2700 persons), followed by those aged 60 and more (1297 persons), and those in the age range of 30-39 (1208 persons). In the youngest group aged 18-29, only 479 people decided to run in the elections to local government bodies. The data in the table below show that this number includes 2420 women and 3270 men, which constitutes $42.53 \%$ and $57.46 \%$ of the total number of candidates respectively.

Table 8. Candidates for councils in the local government elections in the Opolskie Province by gender and age

\begin{tabular}{lccccc}
\hline Age & Number of candidates & Women & Women (\%) & Men & Men (\%) \\
\hline $18-29$ & 479 & 204 & $43 \%$ & 275 & $57 \%$ \\
$30-39$ & 1208 & 582 & $48 \%$ & 626 & $52 \%$ \\
$40-59$ & 2706 & 1157 & $43 \%$ & 1549 & $57 \%$ \\
$60+$ & 1297 & 477 & $37 \%$ & 820 & $63 \%$ \\
Total & $\mathbf{5 6 9 0}$ & $\mathbf{2 4 2 0}$ & $\mathbf{4 3 \%}$ & $\mathbf{3 2 7 0}$ & $\mathbf{5 7 \%}$ \\
\hline
\end{tabular}

Source: own work based on PKW (2018).

Analysing the age of candidates for the offices of mayor, commune leader and city president, one can notice the same characteristics with the predominance of male candidates. In the total number of 178 candidates, there are only 40 women (they constitute $22 \%$ of all candidates) and 138 men (78\% of candidates). The data are presented in Table 9.

Table 9. Candidates for the offices of mayor, commune leader and city president in the local government elections in the Opolskie province in 2018

\begin{tabular}{lccccc}
\hline \multicolumn{1}{c}{ Age } & Number of candidates & Women & Women $(\%)$ & Men & Men $(\%)$ \\
\hline $18-29$ & 3 & 0 & $0 \%$ & 3 & $100 \%$ \\
$30-39$ & 37 & 3 & $8 \%$ & 34 & $92 \%$ \\
$40-59$ & 107 & 29 & $27 \%$ & 78 & $73 \%$ \\
$60+$ & 31 & 8 & $26 \%$ & 23 & $74 \%$ \\
Total & $\mathbf{1 7 8}$ & $\mathbf{4 0}$ & $\mathbf{2 2 \%}$ & $\mathbf{1 3 8}$ & $\mathbf{7 8 \%}$ \\
\hline
\end{tabular}

Source: own work based on PKW (2018).

In these elections, male candidates were dominant, especially in the youngest age group, where there were no female candidates. Over 90\% of the candidates aged 30-39 are also men. In the remaining age groups, more than $73 \%$ of candidates are men. 


\section{Marcin Ociepa}

The participation of the German Minority in the elections deserves special attention in this electoral geography of the Opole Region. The GM owed its success in the local government elections to its members, who have been known to the voters of this region as "our fellow countrymen" and have always been associated with thrift and "good management".

In the 2018 elections, the GM had 33 candidate lists for local government bodies (10), which accounts for $6.04 \%$ of all candidate lists in the province. There were 5 candidate lists for seats on commune councils in communes with a population of more than 20,000 inhabitants (2 councils), 34 candidate lists for seats on district councils (7 councils), and 4 candidate lists for seats on the provincial assembly ( 1 council). As it can be seen in Table 10 , no candidates were appointed for the district-based city council.

Table 10. The candidate lists registered by the German Minority in the local government elections in 2018

\begin{tabular}{lcc}
\hline & candidate lists & councils \\
\hline commune councils in communes with more than 20,000 inhabitants & 5 & 2 \\
city councils in district-based cities & - & - \\
district councils & 24 & 7 \\
provincial assembly & 4 & 1 \\
Total & 33 & 10 \\
\hline
\end{tabular}

Source: own work based on PKW (2018).

Such a large number of candidate lists prepared by the German minority indicates its considerable political activation. This is confirmed by an equally impressive number of candidates for local government bodies, as in total the GM appointed 605 candidates in local government elections: 582 candidates for seats on councils (i.e. 10.22\% of the candidates in the province) and 23 for the offices of mayor or commune leader (12.92\% of the candidates for the executive bodies in the province). In the 2018 election, the German Minority did not put forward any candidates for the office of city president.

For comparison with the leading political forces, 829 candidates were appointed by the Law and Justice party within the region, including 798 candidates for seats on councils and 22 candidates for executive bodies ( 8 candidates for the office of commune leader, 2 candidates for city president, and 12 candidates for the office of mayor) (PKW 2018). The Platform Modern 
Civic Coalition had fewer candidates than the German minority, with a total of 533 candidates: 523 candidates for seats on councils and 10 candidates for the offices of commune leader, mayor, and city president, with 7 candidates for the office of mayor, 1 candidate for the office of city president, and 2 candidates for the office of commune leader (PKW 2018). Thus, the GM appointed a significant number of candidates in the elections, especially for executive bodies, in comparison to the leading national party, although the GM itself is not a party. The discussed data are presented in the table below.

Table 11. A list of the number of candidates of the leading political parties and the GM in the local government elections in the Opole Region in 2018

\begin{tabular}{lccc}
\hline Election & \multicolumn{3}{c}{ Candidates } \\
\hline Candidates for seats on councils and provincial assembly & PiS & PNKO & GM \\
Candidates for the office of commune leader & 798 & 523 & 582 \\
Candidates for the office of mayor & 8 & 2 & 15 \\
Candidates for the office of city president & 12 & 7 & 8 \\
Total & 2 & 1 & - \\
\hline Source: & 829 & 533 & 605 \\
\hline
\end{tabular}

Source: own work based on PKW (2018).

In the electoral landscape, the GM is, therefore, clearly noticeable and represents an important political force. The analysis of the average age of the German minority candidates indicates that they are usually older than the average candidate in the elections in the province. The data presented in Table 12 show that the average age is 49 , while for other candidates it is 47 (Table 7). It is also visible with respect to gender, where the average female candidates' age is 46 and the average male candidates' age is 48 , while for the GM it is 47 and 52, respectively.

The most numerous representation of the GM candidates was in the 40-59 age group (281 out of 582 persons), followed by 144 people aged 60 and over, and 120 in the 30-39 age group. There were only 37 persons in the youngest age group. This corresponds to the general trend in the province. With regard to the German Minority, the dominance of the male candidates is a reflection of that in the region in general, and at the same percentage levels (Table 13). 


\section{Marcin Ociepa}

Table 12. The German minority - the average age of candidates in the 2018 local government elections in the Opolskie Province

\begin{tabular}{lccc}
\hline & Average age & $\begin{array}{c}\text { Average age } \\
\text { of women }\end{array}$ & $\begin{array}{c}\text { Average age } \\
\text { of men }\end{array}$ \\
\hline $\begin{array}{l}\text { Average age of candidates for seats on commune } \\
\text { councils in communes with a population of up to 20,000 } \\
\text { inhabitants }\end{array}$ & 49 & 49 & 49 \\
$\begin{array}{l}\text { Average age of candidates for seats on commune } \\
\text { councils in communes with a population of more than }\end{array}$ & 51 & 47 & 54 \\
$\begin{array}{l}\text { 20,000 inhabitants } \\
\begin{array}{l}\text { Average age of candidates for seats on district-based } \\
\text { city councils }\end{array}\end{array}$ & - & - & - \\
$\begin{array}{l}\text { Average age of candidates for seats on district councils } \\
\text { Average age of candidates for seats on the provincial }\end{array}$ & 51 & 48 & 54 \\
$\begin{array}{l}\text { assembly } \\
\text { Average age of candidates for the office of mayor }\end{array}$ & 49 & 46 & 52 \\
$\begin{array}{l}\text { Average age of candidates for the office of city president } \\
\text { Average age of candidates for the office of commune }\end{array}$ & -48 & 55 & 45 \\
$\begin{array}{l}\text { leader } \\
\text { Total }\end{array}$ & 48 & - & - \\
\hline
\end{tabular}

Source: own work based on PKW (2018).

Table 13. The German minority - candidates for seats on councils in the local government elections in 2018 by age and gender

\begin{tabular}{lccccc}
\hline \multicolumn{1}{c}{ Age } & Number of candidates & Women & Women $(\boldsymbol{\%})$ & Men & Men (\%) \\
\hline $18-29$ & 37 & 18 & $49 \%$ & 19 & $51 \%$ \\
$30-39$ & 120 & 60 & $50 \%$ & 60 & $50 \%$ \\
$40-59$ & 281 & 119 & $42 \%$ & 162 & $58 \%$ \\
$60+$ & 144 & 52 & $36 \%$ & 92 & $64 \%$ \\
Total & $\mathbf{5 8 2}$ & $\mathbf{2 4 9}$ & $\mathbf{4 3 \%}$ & $\mathbf{3 3 3}$ & $\mathbf{5 7 \%}$ \\
\hline
\end{tabular}

Source: own work based on PKW (2018).

In the elections for the offices of the commune leader, mayor and city president, the disparities between the participation of women and men in different age groups are even more pronounced. The data are presented in Table 14.

The analysis shows that men are definitely a majority, with $87 \%$ of candidates, while women only with $13 \%$ of candidates. In the province, this disproportion was at the level of $22 \%$ $78 \%$. In the first two age groups, only men were candidates, while in the 40-59 age group there was only one woman among the 14 candidates. In the oldest age group, only women applied for an office. 
Table 14. The German minority - candidates in the local government elections in 2018 for the offices of commune leaders, mayors and city presidents by age and gender

\begin{tabular}{lccccc}
\hline \multicolumn{1}{c}{ Age } & Number of candidates & Women & Women (\%) & Men & Men (\%) \\
\hline $18-29$ & 1 & 0 & $0 \%$ & 1 & $100 \%$ \\
$30-39$ & 6 & 0 & $0 \%$ & 6 & $100 \%$ \\
$40-59$ & 14 & 1 & $7 \%$ & 13 & $93 \%$ \\
$60+$ & 2 & 2 & $100 \%$ & 0 & $0 \%$ \\
Total & $\mathbf{2 3}$ & $\mathbf{3}$ & $\mathbf{1 3 \%}$ & $\mathbf{2 0}$ & $\mathbf{8 7 \%}$ \\
\hline
\end{tabular}

Source: own work based on PKW (2018).

Therefore, among the GM candidates for councillors, men constituted a majority. As far as the age of the candidates is concerned, most of them were aged 40-59 or 60 and more. The number of women on the GM candidate lists increases in every local government election, although there are still fewer women than men. Female candidate are the most numerous in the age groups of 30-39 and 18-29. Thus, the majority of the GM candidates are men in the two age groups: 40-59 and over 60. The small number of candidates in the 18-29 age group should be emphasized. This may be evidence of the ageing of local GM leaders and the lack of "generational succession" within its ranks.

The activity of the GM, which is noticeable and distinct on a provincial scale with regard to candidate lists and the number of candidates in terms of their age and gender, is in line with the general trends, where men predominate by far and the smallest number of candidates is in the youngest age group, while the oldest age groups have the largest number of candidates.

The elections to the provincial assembly of the Opolskie Province deserve special attention. They were held in 5 constituencies: the constituency 1 comprising the city of Opole, the Opolski district; the constituency 2 comprising the Kluczborski, Namysłowski and Oleski districts, the constituency 3 comprising the Kędzierzyńsko-Kozielski and Strzelecki districts; the constituency 4 comprising the Głubczycki, Krapkowicki and Prudnicki districts; and the constituency 5 comprising the Brzeski and Nyski districts (PKW 2018). In total, 380 candidates from 56 registered candidate lists competed for 30 seats on the provincial assembly (Table 15). 
Table 15. The electoral constituencies in the 2018 election to the provincial assembly in the Opolskie province

\begin{tabular}{|c|c|c|c|c|c|}
\hline \multirow{2}{*}{ Constituency } & \multirow{2}{*}{ Range (districts) } & \multicolumn{4}{|c|}{ Number of } \\
\hline & & Seats & Voters & Registered lists & Candidates \\
\hline 1 & $\begin{array}{l}\text { The city of Opole, Opolski } \\
\text { district }\end{array}$ & 8 & 199,992 & 12 & 97 \\
\hline 2 & $\begin{array}{l}\text { Kluczborski, } \\
\text { Namysłowski, Oleski }\end{array}$ & 5 & 140,585 & 12 & 74 \\
\hline 3 & $\begin{array}{l}\text { Kędzierzyńsko-kozielski, } \\
\text { Strzelecki }\end{array}$ & 5 & 135,182 & 11 & 67 \\
\hline 4 & $\begin{array}{l}\text { Głubczycki, Krapkowicki, } \\
\text { Prudnicki }\end{array}$ & 5 & 133,137 & 11 & 69 \\
\hline 5 & Brzeski, Nyski & 7 & 183,604 & 10 & 73 \\
\hline Total & & 30 & 792,430 & 56 & 380 \\
\hline
\end{tabular}

Source: own work based on PKW (2018).

It is clear that the constituencies 1, 3 (especially this one) and 4 are among those, where there are large concentrations of the German minority members, which is likely to affect the overall picture of the elections. The number of candidate lists in the province constitutes less than $6 \%(5.97 \%)$ of that for the whole of Poland (937). The number of candidates in the province is $5.38 \%$ of the total number of candidates for the provincial assemblies in Poland (7054) (PKW 2018). These low numbers are obviously a consequence of the province's place in the ranking of population and area.

The candidate lists in the elections to the provincial assembly were prepared by 13 electoral committees. Table 16 presents them by the total number of candidates and the number of candidates in the particular constituencies.

The most active of the five constituencies is the constituency 1 (the city of Opole and the Opolski district). It is characterized by the highest number of candidates (97 out of 380 of all candidates), which constitutes $25.52 \%$ of their total number. On average, the electoral committees appointed approximately 29 candidates. The electoral committees of significant political entities, mainly political parties, appointed approximately 40 candidates. The activity of the other entities (with the exception of the Non-Partisan Local Government Activists Electoral Committee and the Green Party Electoral Committee) should be regarded as impressive. Also, 
the activity of the German Minority, which in the elections at the highest level of local government appointed 31 candidates - 10 candidates in the constituency 1 and 7 candidates in the constituencies 2-4. In the constituency 5, the GM did not appoint any candidates, which is not surprising, as its influence in the Brzeski and Nyski districts is negligible.

Table 16. Candidates for the provincial assembly according to the election committees in the 2018 local government elections in the Opole Province

\begin{tabular}{lcccccc}
\hline \multirow{1}{*}{ Election committee } & \multicolumn{9}{c}{ Candidates in the constituency } & Candidates \\
& $\mathbf{1}$ & $\mathbf{2}$ & $\mathbf{3}$ & $\mathbf{4}$ & $\mathbf{5}$ & in total \\
\hline Nonpartisan Local Government Activists & - & 7 & - & - & - & $\mathbf{7}$ \\
Polish Peasants Party (PSL) & 10 & 7 & 7 & 7 & 9 & $\mathbf{4 0}$ \\
Green Party & 8 & - & - & - & - & $\mathbf{8}$ \\
Platform Modern Civic Coalition & 10 & 7 & 7 & 7 & 9 & $\mathbf{4 0}$ \\
Democratic Left Alliance - Left Together & 10 & 7 & 7 & 7 & 9 & $\mathbf{4 0}$ \\
Coalition & 5 & 5 & 5 & 5 & 5 & $\mathbf{2 5}$ \\
Together Party & 5 & 5 & 5 & 5 & 5 & $\mathbf{2 5}$ \\
National Movement & 10 & 7 & 7 & 7 & 9 & $\mathbf{4 0}$ \\
Kukiz'15 & 8 & 5 & 5 & 7 & 8 & $\mathbf{3 3}$ \\
Freedom In Self-Government & 10 & 7 & 7 & 7 & 9 & $\mathbf{4 0}$ \\
Law and Justice (PiS) & 5 & 5 & 5 & 5 & 5 & $\mathbf{2 5}$ \\
The Free And Solidary Election Committee & 10 & 7 & 7 & 7 & - & $\mathbf{3 1}$ \\
German Minority & 6 & 5 & 5 & 5 & 5 & $\mathbf{2 6}$ \\
Silesian Regional Party & $\mathbf{9 7}$ & $\mathbf{7 4}$ & $\mathbf{6 7}$ & $\mathbf{6 9}$ & $\mathbf{7 3}$ & $\mathbf{3 8 0}$ \\
Total & & & & & & \\
\hline
\end{tabular}

Source: own work based on PKW (2018).

Political activity is quite high at the local government level in the Opolskie province. The small area and scarce population contribute to the accumulation and clearer articulation of interests. Even theoretically weaker entities reach for power more willingly by registering electoral lists and appointing candidates. Traditionally, a larger number of candidates compete for seats on governing bodies, as more of these are available, but efforts to take up executive offices can also be seen. The executive bodies have a more individual dimension and are associated with more power granted to a particular person; the offices are prestigious and representative. Having one's own commune leader or mayor is important for local communities, but in the Opole Region this need has a special dimension, connected with the considerable size of the German minority population and its interests. Hence the special activity of the GM in this direction. It determines the specificity of electoral competition in the region. 


\section{Marcin Ociepa}

\section{The results of the local government elections in the Opole Region in 2018}

The results of the electoral competition are as important as the willingness to compete for power, and perhaps even more important. It is worth analysing the results of voting in particular constituencies and for particular committees as well as the overall results of the elections.

The voter turnout in the constituencies was generally below 50\%, except for the constituency 1 , where it was $50.50 \%$. In the remaining constituencies, it reached the following levels: in the constituency $2-49.64 \%$, in the constituency $3-44.28 \%$, in the constituency $4-$ $49.30 \%$, and in the constituency $5-48.54 \%$. Everywhere the percentage of valid votes was over 90\% (PKW 2018).

Table 17. The voting results in the provincial assembly of the Opolskie Province in 2018 by election committees

\begin{tabular}{lcc}
\hline Election committee & Candidate list no. & \% \\
\hline Platform Modern Civic Coalition & 4 & 29.45 \\
Law and Justice (PiS) & 10 & 25.77 \\
German Minority & 12 & 14.64 \\
Polish Peasants Party (PSL) & 2 & 10.72 \\
Kukiz'15 & 8 & 6.06 \\
Democratic Left Alliance - Left Together & 5 & 5.94 \\
Freedom In Self-Government & 9 & 1.54 \\
Together Party & 6 & 1.51 \\
Silesian Regional Party & 13 & 1.13 \\
Free And Solidary & 11 & 1.07 \\
National Movement & 7 & 0.95 \\
Nonpartisan Local Government Activists & 1 & 0.78 \\
Green Party & 3 & 0.45 \\
\hline Soure: & & \\
\hline
\end{tabular}

Source: own work based on PKW (2018).

The percentage of valid votes in the election committees was as follows: the Coalition Platform Modern Civic Coalition Election Committee (list no. 4) with $29.45 \%$ of votes, the Law and Justice Election Committee (list no. 10) with $25.77 \%$, the German Minority Election 
Committee (list no. 12) with 14.64\%, and the Polish Peasant Party Election Committee (list no. 2) with $10.72 \%$. The other election committees recorded one-digit percentage or even less than $1 \%$. The data are presented in the table 17.

The third place of the GM is worth attention; it was reflected in the distribution of seats. Four electoral committees participated in it: the Platform Modern Civic Coalition Election Committee, the Law and Justice Election Committee, the German Minority Election Committee and the Polish Peasant Party Election Committee (PKW 2018).

The largest number of seats (8) were won by the candidates in the constituency 1 , followed by the constituency 5 (7) and 5 seats in the remaining constituencies (Table 18). The election winner was the Platform Modern Civic Coalition Election Committee with 13 seats altogether (seats in each constituency), followed by Law and Justice (10 seats, also seats in each constituency). The GM was third with 5 representatives in the provincial assembly from the constituencies 1, 3 and 4, where it is the most numerously represented. The Polish Peasants Party received only 2 seats, both in the constituency 5 . The data are presented in the table below.

Table 18. The provincial assembly election results by constituencies, candidate lists, and number of seats

\begin{tabular}{|c|c|c|c|c|c|}
\hline \multirow{3}{*}{ Constituency } & \multicolumn{4}{|c|}{ Candidate list number } & \multirow{3}{*}{ Total } \\
\hline & & & & & \\
\hline & 2 & 4 & 10 & 12 & \\
\hline 1 & 0 & 4 & 2 & 2 & 8 \\
\hline 2 & 0 & 3 & 2 & 0 & 5 \\
\hline 3 & 0 & 2 & 1 & 2 & 5 \\
\hline 4 & 0 & 2 & 2 & 1 & 5 \\
\hline 5 & 2 & 2 & 3 & 0 & 7 \\
\hline Total & 2 & 13 & 10 & 5 & 30 \\
\hline
\end{tabular}

Source: own work based on PKW (2018).

The GM, just like in the previous local government elections, managed to introduce its representatives to the provincial assembly of the Opolskie Province. In the 2018 elections, the GM appointed 31 candidates and gained $14.64 \%$ of votes, eventually winning 5 seats. The third place in this competition, behind the important political forces, confirms the fact that the GM is still an important political force at the provincial level. 
The German minority in the local government elections at the commune and district levels in the Opolskie Province in 2018

An analysis of the GM's position at the remaining levels in the elections seems justified, as the GM determines the specificity of the elections at the highest level of local government in the Opole Region.

As Table 19 shows, in the elections to district councils, the highest number of candidates was appointed by the GM in the Opolski (35), Kędzierzyńsko-Kozielski (29) and Strzelecki (27) districts. In the Brzeski, Głubczycki, Namysłowski, and Nyski districts as well as in the city of Opole, no candidate was put forward by the GM in these elections. The GM achieved the best result in the Opolski district, where 12 of its representatives were appointed to the District Council. It also achieved a good result in the Strzelecki district, with 9 seats on the council. 6 councillors were introduced to the Oleski district council, and 5 to the Kędzierzynsko-Kozielski and Prudnicki district councils.

Table 19. The German minority - the results in the local government elections for district councils in 2018

\begin{tabular}{lcccccc}
\hline \multirow{2}{*}{ District/district-based city } & \multicolumn{7}{c}{ District/district-based city } & \\
& \multicolumn{2}{c}{ Number of candidates } & \multicolumn{2}{c}{ Number of seats acquired } \\
& Women & Men & Total & Women & Men & Total \\
\hline Brzeski & 0 & 0 & $\mathbf{0}$ & 0 & 0 & $\mathbf{0}$ \\
Głubczycki & 0 & 0 & $\mathbf{0}$ & 0 & 0 & $\mathbf{0}$ \\
Kędzierzyńsko-Kozielski & 15 & 14 & $\mathbf{2 9}$ & 1 & 4 & $\mathbf{5}$ \\
Kluczborski & 2 & 3 & $\mathbf{5}$ & 0 & 0 & $\mathbf{0}$ \\
Krapkowicki & 3 & 0 & $\mathbf{3}$ & 2 & 0 & $\mathbf{2}$ \\
Namysłowski & 0 & 0 & $\mathbf{0}$ & 0 & 0 & $\mathbf{0}$ \\
Nyski & 0 & 0 & $\mathbf{0}$ & 0 & 0 & $\mathbf{0}$ \\
Oleski & 8 & 10 & $\mathbf{1 8}$ & 3 & 3 & $\mathbf{6}$ \\
Opolski & 16 & 19 & $\mathbf{3 5}$ & 2 & 10 & $\mathbf{1 2}$ \\
Prudnicki & 6 & 7 & $\mathbf{1 3}$ & 1 & 4 & $\mathbf{5}$ \\
Strzelecki & 12 & 15 & $\mathbf{2 7}$ & 2 & 7 & $\mathbf{9}$ \\
Opole - district-based city & 0 & 0 & $\mathbf{0}$ & 0 & 0 & $\mathbf{0}$ \\
Total & $\mathbf{6 2}$ & $\mathbf{6 8}$ & $\mathbf{1 3 0}$ & $\mathbf{1 1}$ & $\mathbf{2 8}$ & $\mathbf{3 9}$ \\
\hline Source: & & & & &
\end{tabular}

Source: own work based on PKW (2018).

The GM was also successful at the commune level, although to varying degrees. In the 2018 elections, the GM confirmed its strong position in communes with a population of up to 20,000 persons, where it appointed altogether 386 candidates and won 203 seats on commune councils. The GM achieved the best result in the Opolski district, where 57 GM councillors 
gained seats on the councils. The GM also enjoys considerable support in communes with a population of up to 20,000 persons in the Strzelecki district, where its candidates gained 43 seats, and in the Kędzierzyńsko-Kozielski district, where they gained 41 seats. It is worth noting that in all these districts the GM won the elections also at the district level. On the other hand, in the Krapkowicki and Oleski districts, the GM candidates did not receive such support, and introduced, respectively, 2 and 6 councillors to the district councils, while in communes with a population of fewer than 20,000 people, 21 seats (the Krapkowicki district) and 29 seats (the Oleski district). The data are presented in Table 20.

Table 20. The German minority - the results in the local government elections for commune councils in 2018

\begin{tabular}{|c|c|c|c|c|c|c|c|c|c|c|c|c|}
\hline \multirow{3}{*}{$\begin{array}{l}\text { District/ } \\
\text { district-based } \\
\text { city }\end{array}$} & \multicolumn{6}{|c|}{$\begin{array}{c}\text { Communes with a population above } 20,000 \\
\text { people }\end{array}$} & \multicolumn{6}{|c|}{$\begin{array}{l}\text { Communes with a population of fewer than } \\
20,000 \text { people }\end{array}$} \\
\hline & \multicolumn{3}{|c|}{$\begin{array}{l}\text { Number of } \\
\text { candidates }\end{array}$} & \multicolumn{3}{|c|}{$\begin{array}{l}\text { Number of seats } \\
\text { acquired }\end{array}$} & \multicolumn{3}{|c|}{$\begin{array}{l}\text { Number of } \\
\text { candidates }\end{array}$} & \multicolumn{3}{|c|}{$\begin{array}{l}\text { Number of seats } \\
\text { acquired }\end{array}$} \\
\hline & Women & Men & Total & Women & Men & Total & Women & Men & Total & Women & Men & Total \\
\hline Brzeski & 0 & 0 & $\mathbf{0}$ & 0 & 0 & $\mathbf{0}$ & 0 & 0 & $\mathbf{0}$ & 0 & 0 & $\mathbf{0}$ \\
\hline Głubczycki & 0 & 0 & $\mathbf{0}$ & 0 & 0 & $\mathbf{0}$ & 0 & 0 & $\mathbf{0}$ & 0 & 0 & $\mathbf{0}$ \\
\hline $\begin{array}{l}\text { Kędzierzyńsko- } \\
\text { Kozielski }\end{array}$ & 3 & 5 & 8 & 0 & 0 & $\mathbf{0}$ & 18 & 37 & 55 & 14 & 27 & 41 \\
\hline Kluczborski & 0 & 0 & $\mathbf{0}$ & 0 & 0 & $\mathbf{0}$ & 7 & 8 & 15 & 6 & 2 & 8 \\
\hline Krapkowicki & 0 & 0 & $\mathbf{0}$ & 0 & 0 & $\mathbf{0}$ & 15 & 20 & 35 & 9 & 12 & 21 \\
\hline Namysłowski & 0 & 0 & $\mathbf{0}$ & 0 & 0 & $\mathbf{0}$ & 0 & 0 & $\mathbf{0}$ & 0 & 0 & $\mathbf{0}$ \\
\hline Nyski & 0 & 0 & $\mathbf{0}$ & 0 & 0 & $\mathbf{0}$ & 0 & 0 & $\mathbf{0}$ & 0 & 0 & $\mathbf{0}$ \\
\hline Oleski & 0 & 0 & $\mathbf{0}$ & 0 & 0 & $\mathbf{0}$ & 27 & 39 & 66 & 10 & 19 & 29 \\
\hline Opolski & 1 & 7 & 8 & 0 & 4 & 4 & 38 & 85 & 123 & 17 & 40 & 57 \\
\hline Prudnicki & 0 & 0 & 0 & 0 & 0 & 0 & 9 & 9 & 18 & 2 & 2 & 4 \\
\hline Strzelecki & 11 & 14 & 25 & 1 & 3 & 4 & 28 & 46 & 74 & 14 & 29 & 43 \\
\hline $\begin{array}{l}\text { Opole - district- } \\
\text { based city }\end{array}$ & & & & & & & & & & & & \\
\hline Total & 15 & 26 & 41 & 1 & 7 & 8 & 142 & 244 & 386 & 72 & 131 & 203 \\
\hline
\end{tabular}

Source: own work based on PKW (2018).

As it can be seen in this table, the GM's position was much weaker in communes with a population of more than 20,000 people. In the 2018 elections, the GM had only 41 candidates for commune councils. In total, the GM candidates won only 8 seats. Even in the districts where the GM was successful in the elections at the district level and in communes with a population of up to 20,000 people, i.e. the Kędzierzyńsko-Kozielski, Opolski and Strzelecki districts, it did not manage to gain many seats. In the Kędzierzynsko-Kozielski district, it did not win any seats, and in the Opolski and Strzelecki districts, it won only 4 seats in each district. In the elections for this 


\section{Marcin Ociepa}

type of communes, the GM did not register any candidate lists in the Brzeski, Głubczycki, Namysłowski and Nyski districts.

Thus, in the 2018 district and commune council elections, the GM won 250 seats. The majority of them in the following districts: Opolski, where it introduced 73 councillors to the district and commune councils; Strzelecki, where it gained 56 seats, and KędzierzyńskoKozielski, where it gained 46 seats. Its result was poorer in the Oleski district (35 seats) and the Krapkowicki district (23 seats).

Table 21. The German minority - the results in the local government elections for the offices of commune leader, mayor and city president in 2018

\begin{tabular}{|c|c|c|c|c|c|c|c|c|c|c|c|c|c|c|c|c|c|c|}
\hline \multirow{3}{*}{ Districts } & \multicolumn{6}{|c|}{$\begin{array}{c}\text { Communes with a population } \\
\text { above } 20,000 \text { people }\end{array}$} & \multicolumn{6}{|c|}{$\begin{array}{l}\text { Communes with a population } \\
\text { of fewer than } 20,000 \text { people }\end{array}$} & \multicolumn{6}{|c|}{ Total } \\
\hline & \multicolumn{3}{|c|}{$\begin{array}{l}\text { Number of } \\
\text { candidates } \\
\text { for village } \\
\text { mayor office }\end{array}$} & \multicolumn{3}{|c|}{$\begin{array}{c}\text { Number of } \\
\text { village mayor } \\
\text { seats } \\
\text { acquired }\end{array}$} & \multicolumn{3}{|c|}{$\begin{array}{l}\text { Number of } \\
\text { candidates } \\
\text { for village } \\
\text { mayor office }\end{array}$} & \multicolumn{3}{|c|}{$\begin{array}{c}\text { Number of } \\
\text { village mayor } \\
\text { seats } \\
\text { acquired }\end{array}$} & \multicolumn{3}{|c|}{$\begin{array}{l}\text { Number of } \\
\text { candidates } \\
\text { for village } \\
\text { mayor office }\end{array}$} & \multicolumn{3}{|c|}{$\begin{array}{c}\text { Number of } \\
\text { village mayor } \\
\text { seats } \\
\text { acquired }\end{array}$} \\
\hline & हूँ & $\sum_{\Sigma}^{\bar{\Xi}}$ & $\frac{\sigma \pi}{0}$ & ڤ్ّ & $\sum^{\Xi}$ & $\stackrel{\frac{\sigma}{0}}{\theta}$ & है & 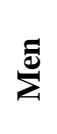 & $\stackrel{5}{\frac{\pi}{0}}$ & : & $\sum_{\Sigma}^{\Xi}$ & हूँ & है & $\sum_{\Sigma}^{\Xi}$ & $\stackrel{5}{\frac{\pi}{0}}$ & ڤँ & $\sum_{\Sigma}^{\Xi}$ & $\stackrel{\pi}{\frac{\pi}{0}}$ \\
\hline Brzeski & 0 & 0 & $\mathbf{0}$ & 0 & 0 & $\mathbf{0}$ & 0 & 0 & $\mathbf{0}$ & 0 & 0 & $\mathbf{0}$ & 0 & 0 & $\mathbf{0}$ & 0 & 0 & $\mathbf{0}$ \\
\hline Głubczycki & 0 & 0 & $\mathbf{0}$ & 0 & 0 & $\mathbf{0}$ & 0 & 0 & $\mathbf{0}$ & 0 & 0 & $\mathbf{0}$ & 0 & 0 & $\mathbf{0}$ & 0 & 0 & $\mathbf{0}$ \\
\hline $\begin{array}{l}\text { Kędzierzyńsk } \\
\text { o-kozielski }\end{array}$ & 0 & 0 & $\mathbf{0}$ & 0 & 0 & $\mathbf{0}$ & 0 & 4 & 4 & 0 & 3 & 3 & 0 & 4 & 4 & 0 & 3 & 3 \\
\hline Kluczborski & 0 & 0 & $\mathbf{0}$ & 0 & 0 & $\mathbf{0}$ & 0 & 0 & $\mathbf{0}$ & 0 & 0 & $\mathbf{0}$ & 0 & 0 & $\mathbf{0}$ & 0 & 0 & $\mathbf{0}$ \\
\hline Krapkowicki & 0 & 0 & $\mathbf{0}$ & 0 & 0 & $\mathbf{0}$ & 0 & 2 & 2 & 0 & 1 & 1 & 0 & 2 & 2 & 0 & 1 & 1 \\
\hline Namysłowski & 0 & 0 & $\mathbf{0}$ & 0 & 0 & $\mathbf{0}$ & 0 & 0 & 0 & 0 & 0 & $\mathbf{0}$ & 0 & 0 & $\mathbf{0}$ & 0 & 0 & $\mathbf{0}$ \\
\hline Nyski & 0 & 0 & $\mathbf{0}$ & 0 & 0 & $\mathbf{0}$ & 0 & 0 & $\mathbf{0}$ & 0 & 0 & $\mathbf{0}$ & 0 & 0 & $\mathbf{0}$ & 0 & 0 & 0 \\
\hline Oleski & 0 & 0 & $\mathbf{0}$ & 0 & 0 & $\mathbf{0}$ & 1 & 3 & 4 & 0 & 1 & 1 & 1 & 3 & 4 & 0 & 1 & 1 \\
\hline Opolski & 0 & 0 & $\mathbf{0}$ & 0 & 0 & $\mathbf{0}$ & 1 & 5 & 6 & 0 & 1 & 1 & 1 & 5 & 6 & 0 & 1 & 1 \\
\hline Prudnicki & 0 & 0 & 0 & 0 & 0 & $\mathbf{0}$ & 0 & 1 & 1 & 0 & 0 & $\mathbf{0}$ & 0 & 1 & 1 & 0 & 0 & 0 \\
\hline Strzelecki & 0 & 1 & 1 & 0 & 0 & $\mathbf{0}$ & 1 & 4 & 5 & 1 & 2 & 3 & 1 & 5 & 6 & 1 & 3 & 4 \\
\hline Total & $\mathbf{0}$ & 1 & 1 & 0 & $\mathbf{0}$ & $\mathbf{0}$ & 3 & 19 & 22 & 1 & 8 & 9 & 3 & 20 & 23 & 1 & 9 & 10 \\
\hline
\end{tabular}

Source: own work based on PKW (2018).

In the direct elections for commune leaders, mayors and city presidents, the GM appointed in total 23 candidates, i.e. fewer than in the 2014 elections, in which it had appointed its candidates in 28 towns and communes (including, for the first time in history, a candidate for the office of president of Opole). This may indicate a weakening position of the GM leaders. In 
10 communes, its candidates won the elections. The GM's stronger position in communes with a population of up to 20,000 people can also be seen on the basis of the results of its candidates for commune leaders. The GM appointed its candidates for these offices in 22 communes of the Opolskie Province: 6 in communes of the Opolski district, 5 in communes of the Strzelecki district, and 4 in communes of the Oleski and Kędzierzynsko-Kozielski districts respectively (Table 21). The GM's best result was achieved in the Strzelecki district, where 3 of its candidates won the direct elections for commune leaders. It was similar in the Kędzierzynsko-Kozielski district. In the Krapkowicki, Oleski and Opolski districts, the GM won the office of commune leader in 1 commune. With regard to the direct elections for mayors and city presidents, the GM appointed its candidate only in 1 commune in the Strzelecki district. The candidate did not win the elections.

\section{Conclusions}

Undoubtedly, the specificity of local government elections in the Opole Region is determined by the activity of the German Minority, which, not being a political party, has become institutionalized and has acted, as if it were a party competing with the actual political parties. The GM is successful in elections at every level (less spectacularly in communes with a population of more than 20,000 inhabitants), and thus can introduce its representatives to governing bodies and pursue its interests.

Based on the data presented in this paper, it can be concluded that the GM participates in elections at all the three levels of the local government, and due to the acquired support, it has the opportunity to co-govern (e.g. at the provincial and district levels), or govern independently (e.g. in communes with a population of up to 20,000 inhabitants). The GM's position is the strongest in councils in communes with a population of up to 20,000 people, and in district councils, in particular in the Opolski, Strzelecki, Kędzierzyńsko-Kozielski districts. The GM does not participate in the political competition in communes with a population of more than 20,000 people.

The analysis of the data concerning the average age of candidates, for both councillors and the offices of commune leaders, mayors and city presidents shows that the GM leaders are "getting older" and thus becoming less "attractive" to younger voters who were very active in the 2018 elections. Moreover, the small number of candidates in the 18-29 age group may indicate a "generation gap" among the GM leaders, which may have an impact on reducing the intensity of the GM's political activity in local government elections in the future. 


\section{Marcin Ociepa}

In 2018, despite a higher voter turnout than in the 2014 elections, the GM won fewer seats; this decline is particularly visible in communes with a population of up to 20,000 inhabitants. This decreasing number of seats won by the GM may also indicate a need to redefine the interests of this national group. In the 1990s, these interests were focused mainly on issues related to identity, culture, or the stopping of the outflow of people of German origin to Germany. At present, due to the accomplishment of most of these objectives, it is necessary for the GM to compete effectively on the local political scene with other actors, and to redefine its objectives.

\section{References:}

Ganowicz, E. (2014). Rywalizacja polityczna mniejszości narodowych $w$ wyborach samorzadowych w Polsce po roku 1989. Opole: Wydawnictwo Uniwersytetu Opolskiego.

Ganowicz, E. \& Opioła, W. (2017). Specyfika partyjnej rywalizacji politycznej w wyborach do samorządu terytorialnego w roku 2014 na przykładzie województwa opolskiego. Przegląd Politologiczny, 2, 136-57.

GUS (2002). Narodowy Spis Powszechny Ludności i Mieszkań 2002 [the 2002 National Census of Population and Housing]. http://stat.gov.pl/spisy-powszechne/narodowe-spisy-powszechne/narodowy-spis-powszechny-

2002/wyniki-narodowego-spisu-powszechnego-2002-narodowosci-oraz-jezyka/ (08/02/2019).

GUS (2019). Rocznik Statystyczny Rzeczypospolitej Polskiej 2019 [Statistical Yearbook 2019]. Warszawa: Główny Urząd Statystyczny (Central Statistical Office).

Journal of Laws (2018). The Act of 11 January 2018 amending certain laws to increase citizens' participation in the process of election, operation and control of certain public bodies (Journal of Laws of 2018, item 130, as amended).

Mazurkiewicz, M. (2015). Wielokulturowy Śląsk Opolski - perspektywa politologiczna, Pogranicze. Polish Borderlands Studies, 3(1), 83-101.

MSWiA (2020). Charakterystyka mniejszości narodowych i etnicznych w Polsce [Characterization of national and ethnic minorities in Poland]. http://mniejszosci.narodowe.mswia.gov.pl/mne/mniejszosci/charakterystykamniejs/6480,Charakterystyka-mniejszosci-narodowych-i-etnicznych-w-Polsce.html\#niemcy (09/02/2020).

Oliver J., E., Ha Shang E., Callen Z. (2012). Local Elections and the Politics of Small-Scale Democracy. Princeton: Princeton University Press.

PAP (2018). Nowela Kodeksu wyborczego już obowiązuje [The amendment to the Electoral Code is already in force]. Gazeta Prawna.pl, 31.01. https://www.gazetaprawna.pl/artykuly/1101266,nowelizacja-kodeksu-wyborczegoweszla-w-zycie-dwukadencyjność-nowa-definicja-x.html (04/03/2019).

PKW (2018). Państwowa Komisja Wyborcza - wybory samorządowe 2018 [National Electoral Commission - 2018 local elections]. https://wybory2018.pkw.gov.pl/ (09/02/2019).

Stoker, G. (1991). The Politics of Local Government. London: Macmillan.

Tybuchowska-Hartlińska, K. (2012). Partycypacja obywatelska na poziomie lokalnym. Preferencje polityczne, 3, 215-25.

Województwo opolskie w liczbach [The Opolskie Province in numbers]. Polska w liczbach [Poland in numbers]. https://www.polskawliczbach.pl/opolskie (09/02/2019).

Wojtasik, W. (2011). Istotność wyborów i jej czynniki w świadomości społecznej. Preferencje polityczne, 2, 205-26. 